\title{
Entrepreneurship Assessment in Higher Education: A Research Review for Engineering Education Researchers
}

\author{
Aileen Y. Huang-Saad, ${ }^{a}$ Christina S. Morton, ${ }^{a}$ and Julie C. Libarkin ${ }^{b}$ \\ aniversity of Michigan, ${ }^{b}$ Michigan State University
}

\begin{abstract}
Background Despite the wide adoption of entrepreneurship by United States engineering programs, there have been few advances in how to measure the influences of entrepreneurial education on engineering students. We believe the inadequate growth in engineering entrepreneurship assessment research is due to the limited use of research emerging from the broader entrepreneurship education assessment community.
\end{abstract}

Purpose This paper explores entrepreneurship education assessment by documenting the current state of the research and identifying the theories, variables, and research designs most commonly used by the broader community. We then examine if and how these theories and constructs are used in engineering entrepreneurship education.

Scope/Method Two literature databases, Scopus ${ }^{\circledR}$ and Proquest, were searched systematically for entrepreneurship education assessment research literature. This search yielded 2,841 unique papers. Once inclusion and exclusion criteria were applied, 359 empirical research papers were coded for study design, theory, variables measured, instruments, and validity and reliability.

Conclusions While there has been growth in entrepreneurship education assessment research, little exchange of ideas across the disciplines of business, engineering, and education is occurring. Nonempirical descriptions of programs outweigh empirical research, and these empirical studies focus on affective, rather than cognitive or behavioral, outcomes. This pattern within the larger entrepreneurship community is mirrored in engineering where the use of theory-based, validated entrepreneurship education assessment instruments generally focuses on the context of intent to start a new company. Given the engineering community's goals to support engineering entrepreneurship beyond business creation, the engineering education community should consider developing assessment instruments based in theory and focused on engineering-specific entrepreneurship outcomes.

Keywords entrepreneurship; research methods; systematic review; theoretical frameworks; student assessment

\section{Introduction}

Global and national calls for a more innovative and entrepreneurial society to support economic growth have motivated engineering colleges and universities to consider new educational reforms (Engineering, 2005; National Academy of Sciences, National Academy of 
Engineering, 2007, 2010). Among these reforms is the call for more engineering-specific entrepreneurship courses, programs and in some cases, degrees (Byers, Seelig, Sheppard, \& Weilerstein, 2013). At the same time, there has been a nationwide effort to increase evidence of student learning in higher education (Massy, Sullivan, \& Mackie, 2013). As new engineering entrepreneurship curricula are put into practice, engineering could benefit from leveraging the depth of knowledge already explored in entrepreneurship education research and assessment.

In this paper, we systematically evaluate the current state of entrepreneurship education assessment by identifying major entrepreneurship assessment themes, theoretical constructs, and the state of construct validity and reliability in work published across the disciplines of business, education, and engineering. This study contributes to engineering education through a systematic synthesis of published research and examination of the research design of specific theory-driven assessment instruments. The research design must be taken into consideration when engineering faculty and researchers attempt to leverage established entrepreneurship assessment theories and constructs, and put them into practice. In particular, we address the differences between business and engineering entrepreneurship education outcomes. This distinction emphasizes the challenges of using existing entrepreneurial intent instruments as defined in the business literature (e.g., the intent to start a business) as a measure of engineering entrepreneurship education. We also highlight the limited use of theory to inform current work in engineering entrepreneurship education assessment. These findings will help engineering education faculty (a) leverage existing research products, including theories and assessment instruments, where appropriate, and (b) identify new avenues of entrepreneurship research for the engineering education research community, including the need for new validated assessment instruments. Careful development of a research agenda for engineering entrepreneurship education can help build a research base for university administrators and policy leaders who need to understand the impact of entrepreneurship education in science and engineering.

The primary research question driving this work is "What are the fundamental theories used to inform entrepreneurship education assessment research in business, education and engineering, and how are these theories operationalized in assessment?" We address this question through a systematic literature review of entrepreneurship education papers cited in two databases representing the three disciplines of business, education, and engineering. Based on our findings, we not only identify fundamental theories, themes, and constructs used in prior work but we also explain how the research design frames both the value of entrepreneurship education and the interpretation of research findings. Finally, we recognize the limited uses of theory to inform engineering entrepreneurship education and propose new areas of research that should be explored specific to engineering entrepreneurship.

\section{Growth of Entrepreneurship Education in Business Schools}

American entrepreneurship education originated in United States business schools after World War II, with Harvard Business School offering the first entrepreneurship class (Katz, 2003; Vesper \& Gartner, 1997) between 1945 and 1947 as students returning from the war were facing a collapsed weapons industry (Vesper \& Gartner, 1997). While interest in entrepreneurship education waxed and waned, the venture capital community became prominent in the 1960s when the government approved the creation of small business investment companies. Universities responded by gradually increasing the number of entrepreneurship courses being offered (Gompers, 1994), and by 1970, 16 universities were offering such 
courses (Vesper \& Gartner, 1997). By 1999, the discipline had grown from a small handful of courses to more than 2,200 entrepreneurship courses offered at over 1,600 American colleges and universities (Katz, 2003). As of the mid-2000s, most of these entrepreneurship courses were based in business schools and could be characterized in terms of building companies (firm-creation) and making profit (wealth-creation) (Katz, 2003).

Since the early 2000s, business entrepreneurship research has expanded the definition of entrepreneurship beyond building companies (Loi, Castriotta, \& Di Guardo, 2016; Neck, Greene, Branson, \& Ash, 2011; Shane \& Venkataraman, 2000) and has been exploring new active learning pedagogical practices (Neck et al., 2011). The most significant change to come from this expansion is the recognition that entrepreneurship is itself a complex system. It is "about creating new opportunities and executing in uncertain and even currently unknowable environments" (Neck et al., 2011), and, as such, learning the entrepreneurial process adds value to all students (Rae, 2010). Business entrepreneurship education now includes aspects of business (e.g., strategy, finance, leadership), the social sciences (e.g., sociology, anthropology), and secondary skills (e.g., living with uncertainty, creating, opportunity identification) (Neck et al., 2011) in the context of new business development. While the definition of entrepreneurship has been changing, business entrepreneurship is still taught in the context of new business development, and outcome metrics are measured in the context of the intent to start a new business.

Although entrepreneurship has traditionally been a business school endeavor, the demand for entrepreneurial training in other disciplines has increased globally since the 1990s (Wasley, 2008). The global interest in entrepreneurship is a result of the association between entrepreneurship and economic growth, which has motivated policy makers to focus on cultivating and sustaining entrepreneurship (Reynolds, Camp, Bygrave, Autio, \& Hay, 2000). Expanding the footprint of entrepreneurship education across universities is occurring, particularly among technologists, engineers, and scientists interested in commercializing their research. Interest in such expansions is a result of the recognition that educating scientists and engineers is a critical component of a successful university entrepreneurial ecosystem (Belitski \& Heron, 2017). At the same time, exposure to entrepreneurship is being offered to children as young as elementary age, as well as to undergraduates and graduate students (Daniel \& Kent, 2005). A survey in 2010 determined that 4 in 10 young people (ages 8-21, $n=5,077)$ in the United States would like to start their own business, with $60 \%$ of those youth who either had or wanted to start their own businesses indicating that education played a key role in their entrepreneurial interests (Kauffman Foundation, 2010).

Although entrepreneurship education programs are becoming widely adopted in K-12 and postsecondary education (Regele \& Neck, 2012; Sorgman \& Parkison, 2008), whether entrepreneurship can be considered an academic discipline remains subject to debate. While business schools legitimized entrepreneurship by incorporating it into the curriculum, hiring faculty, and establishing academic journals (Katz, 2003), scholars agree that the discipline is still quite young (Katz, 2008; Kuratko, 2005). In addition, Colby, Ehrlich, \& Sullivan (2011) recognized the challenges inherent in incorporating new concepts of entrepreneurship into existing business school structures (Colby et al., 2011). In 2005, Kuratko systematically identified several challenges faced by business school entrepreneurship faculty as they worked toward developing entrepreneurship as an academic discipline (Kuratko, 2005). Perhaps most importantly, the discipline is challenged to identify best practices for conducting high-quality research in high impact journals and establishing a common definition of entrepreneurship. Recognizing the potential for growth in the discipline and the potential role entrepreneurship 
could play in the future of business schools, Kuratko used his 2005 paper as a call to action for his colleagues to take a leadership role in the future of entrepreneurship education and research.

\section{Growth of Entrepreneurship Education in Engineering}

As the business community continued to debate the maturity of entrepreneurship in academic institutions, a new community of entrepreneurship educators began to emerge outside of business schools at the beginning of the of the 21st century (Katz, 2003; Kuratko, 2005; Shartrand, Weilerstein, Besterfield-Sacre, \& Golding, 2010). As of 2008, more than half of American Society of Engineering Education (ASEE) schools reported offering entrepreneurship options, with approximately $25 \%$ reporting more comprehensive programs such as minors or certification programs (Shartrand et al., 2010). Continued national interest in engineering entrepreneurship at a federal and national level is signaled through faculty-focused training via the National Science Foundation's (NSF) Epicenter Pathways Initiative (Sheppard et al., 2015), the NSF I-Corps Program (VentureWell, 2016), and the Kern Entrepreneurship Engineering Network (KEEN) (Blessing, Mekemson, \& Pistrui, 2008; Fry, Jordan, Leman, Garner, \& Thomas, 2010). A 2015 survey of ASEE members $(n=171)$ representing 100 institutions indicated that faculty and administrators strongly agree that engineering students should have access to innovation and entrepreneurship education (Peterfreund, Costache, Chen, Gilmartin, \& Sheppard, 2016).

Like the business community, engineering communities interested in entrepreneurship have begun to coalesce and develop an academic entrepreneurship education community through the development of engineering-specific entrepreneurship centers and programs (Gilmartin, Chen, \& Estrada, 2016), conference divisions (e.g., ASEE/Entrepreneurship Division, VentureWell Open), networks (KEEN), and the creation of new journals focused on engineering entrepreneurship (e.g., Journal of Engineering Entrepreneurship). Despite a diverse set of goals and definitions of entrepreneurship (Gilmartin et al., 2016), engineering entrepreneurship programs seek to integrate business skills and innovation in STEM education by offering classes and programs that promote creativity, product development, opportunity identification, teamwork, and communication (Duval-Couetil, Shartrand, \& ReedRhoads, 2016). The goals of these programs range from supporting students in creating new businesses to developing an entrepreneurial mindset, with most linked to definitions of entrepreneurship that are business- rather than mindset-oriented. Given the large number of courses engineering students are required to take (Standish-Kuon \& Rice, 2002), engineering entrepreneurship education programs have utilized co-curricular programming to deliver entrepreneurship education experiences (Duval-Couetil et al., 2016; Gilmartin et al., 2016).

While the creation of engineering entrepreneurship programs seems to address the need for undergraduate engineering reforms, "programs do not always measure progress towards their goals" (Gilmartin et al., 2016, p. 2058); as such they are more likely to measure output metrics such as enrollment and degrees as opposed to evidence of program impact on individual students (Gilmartin et al., 2016). The limited attention given to engineering entrepreneurship education impact and assessment can be attributed to many challenges. Duval-Couetil (2013) delineated many of these challenges from the importance of programs reaching consensus on learning outcomes to setting assessment as a priority. Gilmartin et al. (2016) also found that programs often do not share a common understanding of the meaning of entrepreneurship, both within and across programs. Without a shared definition, appropriate measures for assessing program impacts cannot be identified. 
Three recent attempts to better understand the current state of measures and instruments for evaluating the impact of engineering entrepreneurship education have set the stage for understanding the scale of the problem (Da Silva, Costa, \& de Barros, 2015; Menold, Jablokow, Zappe, Reeves, \& Kisenwether, 2015; Purzer, Fila, \& Nataraja, 2016), with all three seeking to aggregate current approaches to entrepreneurship education assessment. Da Silva et al. (2015) used a new bibliographic data-mining model, Webibliomining, to map fundamental entrepreneurship education papers with respect to journals with the largest number of published articles and prolific authors. Menold et al. (2015) and Purzer et al. (2016) critiqued the quality of selected entrepreneurship education assessment practices, determining that a wide variety of purposes, methods, and instruments were used to assess engineering entrepreneurship education with varied research quality. While both Menold et al. and Purzer et al. commented on the value of grounding assessment in the context of student learning and/or theory, none of these three papers detailed the current theoretical approaches being used to guide entrepreneurship education research, a critical omission as "link[ing] research to relevant theory" is one of the fundamental guidelines for conducting high quality education research (Streveler \& Smith, 2006, p. 103).

This study addresses the missing link between engineering entrepreneurship education research and theoretical grounding by synthesizing the current state of entrepreneurship education assessment literature across business, education, and engineering. Specifically, we ask, "What are the fundamental theories used to inform entrepreneurship education assessment research in business, education and engineering? What are the research designs? What variables are being measured? And what is the current state of instrument development with respect to validity and reliability?" We then aggregate the fundamental theories underlying entrepreneurship education research, evaluate the common methods used to assess outcomes across the three disciplines, and interpret how theories and assessments can be applied to engineering entrepreneurship education specifically.

\section{Methods}

This study follows pre-established methods used in conducting systematic literature reviews (Borrego, Foster, \& Froyd, 2014; McGowan \& Sampson, 2005). Two databases covering the three major research disciplines (science/engineering, education, and business) most relevant to our questions were searched: Elsevier's Scopus for engineering literature and ProQuest, which subsumes the education database ERIC and the business database ABI/INFORM Complete.

The same search criteria were used for both databases on September 3, 2015, ("entrepreneurship education" OR "entrepreneurial education") AND ("measurement" OR "instrument" OR "assessment") in the general search block for all fields. Results were limited to peer-reviewed journals and proceedings published in English. In the interest of exploring the full scope of literature in entrepreneurship education over time, no limitations were placed on publication dates.

The initial literature search resulted in a total of 3,123 citations (including duplicates across the two databases) representing a wide variety of publication sources. Proquest $(n=$ $1,780)$ included papers from as early as 1950 , while the Scopus dataset $(n=1,343)$ included papers from 1988 onwards. Although Proquest contained earlier literature, the Scopus search included more publication sources (journals/proceedings)—496 (Scopus) versus 393 (Proquest). The analysis of the two searches identified 282 duplicate entries, which were subsequently extracted, yielding a final dataset of 2,841 unique papers. Inclusion and exclusion criteria, which 
were developed iteratively as two authors independently examined the papers (Table 1), were established to identify empirical studies in entrepreneurship education specific to higher education. Thus, studies that included only entrepreneurs or participants not affiliated with a higher education institution or program (e.g., K-12, veterans, tourism/hospitality industry, among others) were excluded. A total of 2,482 citations were excluded from the literature review based on the criteria seen in Table 1, resulting in a total 359 papers to be coded for study design, theory, variables measured, instruments, and validity/reliability.

\section{Analysis}

One of the authors reviewed 238 abstracts of the resulting 359 papers to identify potential features for a coding rubric. Two authors then coded 12 full papers to continue development toward a final coding rubric. During rubric development, these two authors co-coded this subset of papers, discussed issues, and iteratively revised the rubric until agreement was reached. The rubric was designed to identify details of current entrepreneurship education study designs, including the theories used to inform the studies, the methods used, the variables measured, and the validity and reliability checks. A third author provided feedback during rubric development to identify areas in the rubric needing clarification.

Each study was coded as either a characterization or intervention study. Characterization studies were defined as those that described the nature of a group or setting, while intervention studies examined how respondents' participation in a particular event (e.g., an entrepreneurship class or training program) influenced an individual outcome. Characterization studies included only dependent variables, whereas intervention studies included both dependent and independent variables. The setting of each study was also coded as a single setting versus multiple settings. Studies completed in one institution, city, or country were coded as single settings, whereas data collected across multiple institutions, settings, or geographic locations were coded as multiple settings.

Table 1 Literature Review Inclusion and Exclusion Criteria

\begin{tabular}{|c|c|}
\hline Inclusion criteria & Exclusion criteria \\
\hline \multirow{2}{*}{$\begin{array}{l}\text { International and domestic journals } \\
\text { and conference proceedings }\end{array}$} & Literature reviews \\
\hline & Book reviews \\
\hline $\begin{array}{l}\text { Empirical data collected from } \\
\text { human participants }\end{array}$ & $\begin{array}{l}\text { Any articles that do not have the word entrepreneurship or any of its } \\
\text { variations in the abstract or in the keywords }\end{array}$ \\
\hline \multirow{2}{*}{$\begin{array}{l}\text { Study participants must be } \\
\text { entrepreneurs or faculty, } \\
\text { students, and administrators } \\
\text { in higher education }\end{array}$} & $\begin{array}{l}\text { Studies with no participants who were associated with a higher } \\
\text { education institution }\end{array}$ \\
\hline & $\begin{array}{l}\text { Studies regarding public policy or the macroeconomic environment } \\
\text { such as entrepreneurial efforts of a country }\end{array}$ \\
\hline \multirow{3}{*}{$\begin{array}{l}\text { Studies must be focused on training } \\
\text { entrepreneurs, entrepreneurial } \\
\text { characteristics, or participant } \\
\text { perceptions of entrepreneurship }\end{array}$} & $\begin{array}{l}\text { Studies focused on small businesses, unless entrepreneurship is } \\
\text { specifically cited as relevant to the publication }\end{array}$ \\
\hline & Papers describing anecdotal results or offering program descriptions \\
\hline & Papers specifically describing a learning tool used in entrepreneurship \\
\hline \multirow{5}{*}{$\begin{array}{l}\text { Studies should focus on } \\
\text { microentrepreneurial } \\
\text { environments such as start-ups } \\
\text { or entrepreneurship training } \\
\text { programs }\end{array}$} & education \\
\hline & Papers that do not collect data from human participants \\
\hline & Studies that evaluate business incubators \\
\hline & $\begin{array}{l}\text { Studies that claimed to use case study methodology, as the term was } \\
\text { inconsistently applied }\end{array}$ \\
\hline & Studies that did not specifically delineate a research methodology section \\
\hline
\end{tabular}


Participants were identified as students (undergraduate or graduate), alumni, college faculty or administrators of a college/postgraduate program, or entrepreneurs. Participants were also classified as belonging to business or engineering disciplines, when provided. For this review, business included marketing, economics, strategy, accounting, management, organizational studies, or operations. If the publication did not explicitly characterize the participants as belonging to one of the previous business subdisciplines or engineering, they were coded as other disciplines. Studies were also coded for the independent variables measured, including age, gender, ethnicity/race, nationality, parents' education, and any other independent variables collected from participants. The nationality of participants was documented when explicitly indicated in a study; otherwise, the country where the data collection took place was used as a proxy for student nationality.

The rubric took a liberal approach in capturing the use of theories to inform entrepreneurship education assessment research. Theories or theoretical frameworks discussed prior to a paper's methods section were coded, and the data collection strategies used (e.g., open-ended survey, interviews, observations, Likert surveys) were also coded. We characterized the types of data collected as qualitative or quantitative for descriptive purposes, with the former being non-numerical data and the latter the numerical data. If authors used a previously published and validated scale (instrument) in their study, the paper was coded as such, with the specific scale and citation being recorded. In addition, any documentation of validity, reliability, or trustworthiness of the empirical study was also recorded.

The framework of Social Cognitive Theory (SCT, Bandura, 1986) was adopted to provide a lens for characterizing the assessment variables measured. This theory is particularly relevant to entrepreneurship education research because its focus on behaviors fits well with the overarching goal of entrepreneurship education, which is to encourage entrepreneurial outcomes in the form of individual activity. SCT posits that an individual's cognition, affect and developmental history will interact with environmental variables to produce specific behaviors. In our evaluation of assessment, we coded for affective, cognitive, and behavioral variables. Behavioral variables are those actions a person actually takes, such as starting a business. However, researchers also often measure intended behaviors rather than actual behaviors because behavior is a long-term outcome that can be difficult to measure. Cognitive variables include an individual's knowledge or skills, such as a person's ability to communicate or their leadership skills. Finally, affect encompasses a host of variables that are unique to individuals, including feelings, motivations, perceptions, and attitudes. For example, in entrepreneurship education, self-efficacy and entrepreneurial mindset are common affective variables.

Two authors independently coded 25 papers to establish inter-rater reliability based on the final coding rubric. The average intraclass correlation across these two raters was 0.97 ( $\mathrm{min}=$ 0.96 and $\max =0.97$ ). Since an intraclass correlation close to 1.0 suggests a nearly perfect positive correlation, the coding rubric used here exhibited excellent inter-rater reliability. These two authors each coded half of the remaining papers while the third author provided a continual review of the coding progress to ensure reliability was maintained.

\section{Results}

\section{Descriptive Statistics of Initial Literature Search}

General trends observed in the initial literature search prior to the application of the inclusion and exclusion criteria (Table 1) are discussed first. Both the Proquest and Scopus databases exhibit similar increases in entrepreneurship-related publications beginning at about the 
turn of the 21st century (Figure 1). An analysis of the "entrepreneurship education" paper sources indicates that close to $50 \%$ of all of these publications reviewed are represented by approximately 53 journals. In addition, the overlap analysis found that while both databases were searched using the same criteria, the citations identified within the same publication source were not always consistent. For example, Scopus identified 75 citations for Education and Training, whereas Proquest identified 158; this discrepancy was likely due to the older literature housed within Proquest and differences in indexed years for the shared journals.

In the Scopus search, 46 publication sources contained the word engineer (or a variant) in their titles, including conference proceedings from IEEE (Institute of Electrical and Electronics Engineers) or ASEE. A total of 180 engineering-related citations emerging from 46 engineering publications sources were identified, all of which were published in or after 2001. No engineering-specific journals or proceedings were identified by the Proquest search. An increase in entrepreneurship-related publications in the engineering-specific journals follows the same trajectory as the general Proquest and Scopus searches (Figure 1).

\section{Descriptive Statistics of Empirical Studies Reviewed}

The 359 empirical studies identified based on the inclusion and exclusion criteria were coded for study design, theory, variables, instruments, and validity and reliability criteria. These

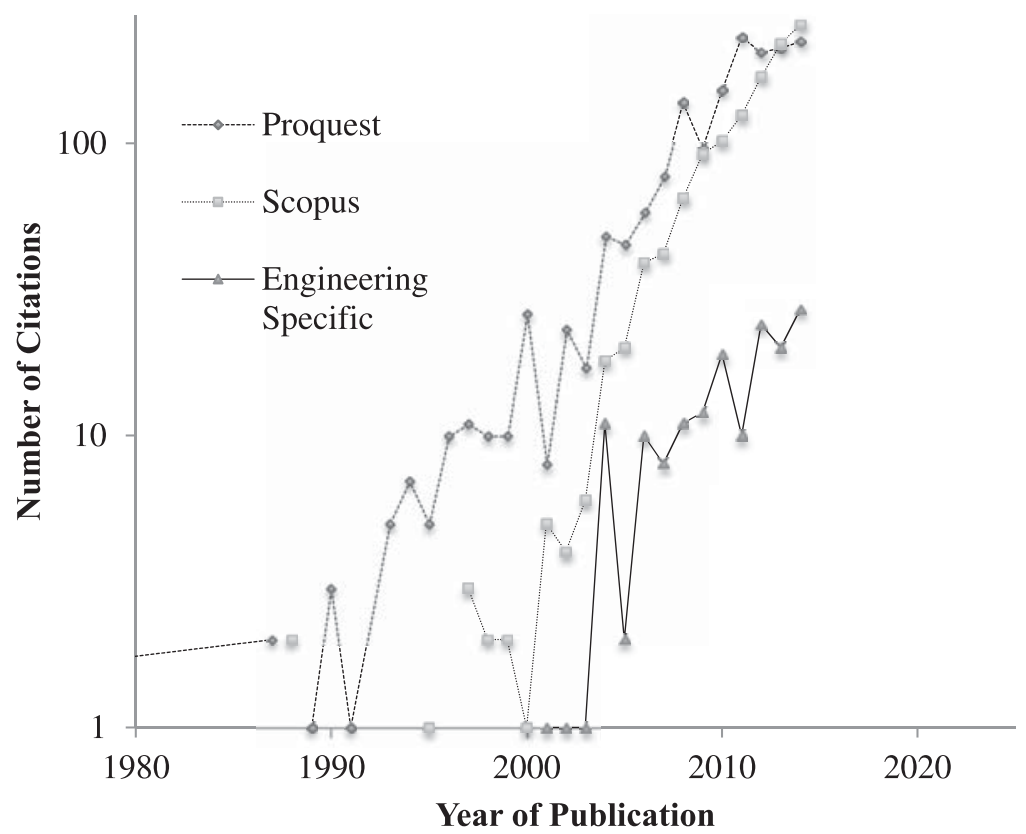

Figure 1 Number of entrepreneurship education citations per year identified in the Proquest and Scopus databases. Both the Proquest and Scopus databases exhibit similar increases in entrepreneurship-related publications, with the increase beginning at about the turn of the 21st century. Engineering specific entrepreneurship education citations also increased at the turn of the 21 st century 
studies spanned 137 different journals, although 13 journals represented $50 \%$ of the studies included (Table 2). Only one engineering-specific source, ASEE Annual Conference and Exposition Proceedings, is found in the list of 13 journals representing 50\% of the studies included in this literature review (Table 2).

Study type and population The majority of the 359 entrepreneurship education studies analyzed here were classified as characterization studies (67\%), and most utilized quantitative approaches (87\%, Table 3). Participants were typically undergraduate students, with most studies focusing on business school students (60\%) and $20 \%$ considering engineering students. While this literature review was focused on studies with participants associated with a higher education institution, it should be noted that $7 \%$ of the studies included entrepreneurs as a comparison sample population as well. The most common basic measure across studies was gender (71\%), followed by age (57\%). Participant ethnicity and race were reported less frequently (12\%), and even fewer studies documented parents' education level (3\%).

Theories Approximately 50\% of the studies cited theories prior to their methods section, although very few authors discussed the link between these theories and their research design. Given this lack of theoretical grounding, a liberal approach to coding theories was used in this review. If a study mentioned a theory at any point prior to the methods section, the paper was coded as containing a theory though the authors did not need to explicitly state that the theory provided the foundation for their research.

We found that 473 theories were referenced in the 359 empirical studies, representing 153 distinct theories. The three predominant theories cited were Ajzen's Theory of Planned Behavior (TPB, 26\%) (Ajzen, 1991), Bandura's SCT (14\%) (Bandura, 2001), and Shapero's Model of Entrepreneurial Event (5\%) (Shapero \& Sokol, 1982). All other theories were cited in $2 \%$ or fewer of the studies reviewed. A brief discussion of these three theories is given

Table 2 Publication Sources That Represent Placement of 50\% of All Entrepreneurship Education Assessment Empirical Studies

\begin{tabular}{lc}
\hline Journal title & $\begin{array}{c}\text { Number } \\
\text { of citations }\end{array}$ \\
\hline Education and Training & 46 \\
ICSB* World Conference Proceedings & 20 \\
ASEE Annual Conference and Exposition, Conference Proceedings & 19 \\
International Entrepreneurship and Management Journal & 17 \\
Journal of Small Business and Enterprise Development & 17 \\
International Journal of Entrepreneurial Behaviour E Research & 13 \\
African Journal of Business Management & 12 \\
Journal of Business and Entrepreneurship & 10 \\
International Journal of Management Education & 8 \\
Journal of Entrepreneurship Education & 8 \\
Entrepreneurship Theory and Practice & 5 \\
International Journal of Business and Management & 4 \\
\hline
\end{tabular}

*ICSB, International Council for Small Business. 
Table 3 Descriptive Statistics of Entrepreneurship Education Empirical Studies

\begin{tabular}{lc}
\hline Type of study & $\begin{array}{c}\text { Number of } \\
\text { studies (\%) }\end{array}$ \\
\hline Intervention & $119(33)$ \\
Characterization & $240(67)$ \\
Participants & \\
Undergraduates & $270(75)$ \\
Graduate students & $84(23)$ \\
Undergraduate Alumni & $10(3)$ \\
Graduate Alumni & $10(3)$ \\
Faculty & $40(11)$ \\
Entrepreneurs & $24(7)$ \\
Disciplines & \\
Business & $214(60)$ \\
Engineering & $72(20)$ \\
Other disciplines & $153(43)$ \\
Basic measures & \\
Age & $206(57)$ \\
Gender & $255(71)$ \\
Ethnicity/Race & $44(12)$ \\
Parents' education & $9(3)$ \\
Theories/experimental protocols/measures & \\
Theoretical framework & $38(11)$ \\
Referenced theory & $190(53)$ \\
Qualitative methods & $68(19)$ \\
Quantitative methods & $312(87)$ \\
Author used an existing scale & $203(57)$ \\
Attempted validity/reliability testing & $232(65)$ \\
\hline
\end{tabular}

below as an introduction to the theoretical underpinnings of entrepreneurship education assessment research.

Ajzen's (1991) TPB, a prominent psychological behavioral intention model that is an extension of the Theory of Reasoned Action (Fishbein \& Ajzen, 1975), is commonly used to explain and predict human behavior (Kolvereid, 1996) in a specific context. Intentions, which are assumed to align with motivators of behavior, indicate how much effort individuals can be expected to put into planning and performing behaviors. According to TPB, intent is a fundamental cognitive determinant of behavior: the stronger an individual's intent to engage in a specific behavior, the more likely they are to do so. According to TPB, behavior is influenced by an individual's general attitudes and beliefs as well as such external factors as (a) attitudes toward behavior, (b) subjective norms, and (c) perceived behavioral control. Attitude toward behavior refers to the degree to which an individual has a positive or negative opinion about a behavior, while subjective norms refer to the perceived social pressure for an individual to perform or not perform a behavior. Perceived behavioral control refers to the individual's perception of the ease or difficulty involved in performing a behavior.

Like TPB, Shapero's 1982 Model of the Entrepreneurial Event (SEE) is an intention model. According to Shapero and Sokol (1982), an entrepreneurial event is composed of five 
actions: (1) initiative taking, (2) consolidation of resources to accomplish a particular objective, (3) management of the organization by those who initiated the venture, (4) relative autonomy, and (5) risk-taking. To be classified as an entrepreneurial event, all five of these actions must be present. SEE suggests that the formation of an entrepreneurial event is typically preceded by a life path change which could be triggered by a number of factors, including a positive pull from another person (e.g., encouragement from a mentor), being between opportunities (e.g., graduating from school), or a negative experience of displacement (e.g., getting fired). Once a life path change has occurred, the perceived desirability and feasibility of the entrepreneurial event strongly influences an individual's decision to act. Perceived desirability describes a person's interest in engaging in entrepreneurship, an interest that is generally influenced by exposure to entrepreneurial activity either through personal experience or observing others such as parents or mentors. Perceived feasibility pertains to a person's beliefs that they could realistically start a new venture. These beliefs could be influenced by, for example, the presence of family support or financial resources.

Bandura's SCT (Bandura, 1986) asserts that human action is a result of the interplay between an individual's personal characteristics, behavior, knowledge, and environment. The central components of this theory are self-regulation, self-efficacy, symbolizing capability, and forethought capability. Self-regulation reflects the notion that a person's behavior is largely motivated and regulated by internal standards and the evaluation of the outcomes of one's action. Self-efficacy, an individual's judgment of their own ability to organize and perform actions, influences the amount of effort that one might expend on a particular activity and one's persistence in spite of obstacles faced (Bandura, 1986). Symbolizing capability describes a person's ability to test potential courses of action in theory and make decisions based on projected outcomes. Related to symbolizing capability is forethought, which is a person's ability to anticipate the potential consequences of their actions or to plan courses of action in response to imagined futures.

\section{Variables}

The type of variable measured in evaluation of entrepreneurship programs should generally be determined by the theory driving the research question. Since SCT was the theory driving this part of the literature review, studies were analyzed to determine the presence of affective, behavioral, and cognitive human subjects variables. Seven studies did not measure any of these three variable types. Instead, these studies focused on characteristic measures, such as participant demographics (i.e., gender, educational background, or age) or environmental factors, such as entrepreneurial support structure or social network. Of the remaining 352 studies, 310 considered affective variables, 218 behavioral variables, and 49 cognitive variables. Two of these variable types were considered by 173 studies, with only 26 studies looking at all three categories of variables. The most common constructs within each variable type were investigated to determine the variables related to entrepreneurship that the research community at large considers to be most important to study.

Perceptions were the most commonly considered affective variables (Table 4), with some being unique to individual studies while others, such as perceived behavioral control, being tied to broader literature emerging from other disciplines. Variables tied to these more extensive bodies of literatures were often investigated using similar instruments, validated in one setting and applied to a new setting, while locally derived variables, those that emerged from the specific context under study, were less likely to be investigated using validated instruments. This dichotomy between locally derived variables and widely used variables was 
Table 4 Variables Most Commonly Present in Studies Analyzed (See Table 5 for Example Scales and References)

\begin{tabular}{|c|c|c|}
\hline Variable type & Examples or details & $\begin{array}{l}\text { Number of studies } \\
\text { (\% of category) }\end{array}$ \\
\hline \multicolumn{3}{|l|}{ Affective variables $(n=310)$} \\
\hline Perceptions & $\begin{array}{l}\text { Perceptions of new venture opportunities; } \\
\text { perceived behavioral control }\end{array}$ & $123(34)$ \\
\hline Attitude & $\begin{array}{l}\text { Entrepreneurial attitude; attitude toward } \\
\text { failure }\end{array}$ & $87(24)$ \\
\hline Self-efficacy/self-esteem & Entrepreneurial self-efficacy & $57(16)$ \\
\hline Entrepreneurial orientation & Includes proactiveness, risk taking & $49(14)$ \\
\hline Creativity & Creativity; creation process & $36(10)$ \\
\hline Motivation & Motivation to open a business & $30(8)$ \\
\hline Beliefs & Behavioral beliefs; locus of control & $24(7)$ \\
\hline $\begin{array}{l}\text { Entrepreneurial } \\
\text { mindset }\end{array}$ & $\begin{array}{l}\text { State of mind drawing people toward } \\
\text { innovation, creation, and opportunity. }\end{array}$ & $13(4)$ \\
\hline \multicolumn{3}{|l|}{ Behavioral variables $(n=218)$} \\
\hline $\begin{array}{l}\text { Entrepreneurial } \\
\text { intentions }\end{array}$ & $\begin{array}{l}\text { Future plans to engage in entrepreneurial } \\
\text { activity }\end{array}$ & $105(48)$ \\
\hline Entrepreneurial behaviors & Entrepreneurial activities (present or past) & $37(17)$ \\
\hline Work experience & Generic work experience & $26(12)$ \\
\hline Plans/goals & Entrepreneurial career aspirations & $19(9)$ \\
\hline Training & Coach, trainer, teacher activities & $16(7)$ \\
\hline \multicolumn{3}{|l|}{ Cognitive variables $(n=49)$} \\
\hline Skills & Business competencies & $22(45)$ \\
\hline Knowledge & Financial literacy & $8(16)$ \\
\hline
\end{tabular}

evident in other variable types as well. Attitudes, often tied to motivations to pursue further study or initiate a new business, self-efficacy/esteem, and creativity variables were most commonly analyzed through locally derived instruments. On the other hand, entrepreneurial orientation and entrepreneurial intention were widely investigated, often through the use of pre-existing instruments. Other affective variables found in the studies include a willingness to engage in entrepreneurship, expectations, and psychological ownership, among others.

Behavioral and cognitive variables were much less frequently studied than affective variables. Studies focused on measuring behavior almost exclusively relied on self-reports of planned future behaviors rather than current or past activities. By far future behavior was the most studied entrepreneurial intention, followed by career plans related to entrepreneurship. Only $10 \%$ of the studies considering behavioral variables measured past or present activities. Finally, two cognitive variables, skills and knowledge, were the most common cognitionrelated constructs used in the works investigated here. Constructs, such as entrepreneurial skills, were often generically described, with authors occasionally elucidating specific concepts, such as financial literacy, seen as important for entrepreneurial success. Use of generic descriptions for measured constructs prohibited further detailed analysis.

\section{Measures}

Two hundred and three $(203,57 \%)$ of the 359 publications utilized existing measures in their studies, with the 11 most commonly used being quantitative (Table 5). These scales all evaluated affect or behavior, with no common measures identified for cognitive variables. The 


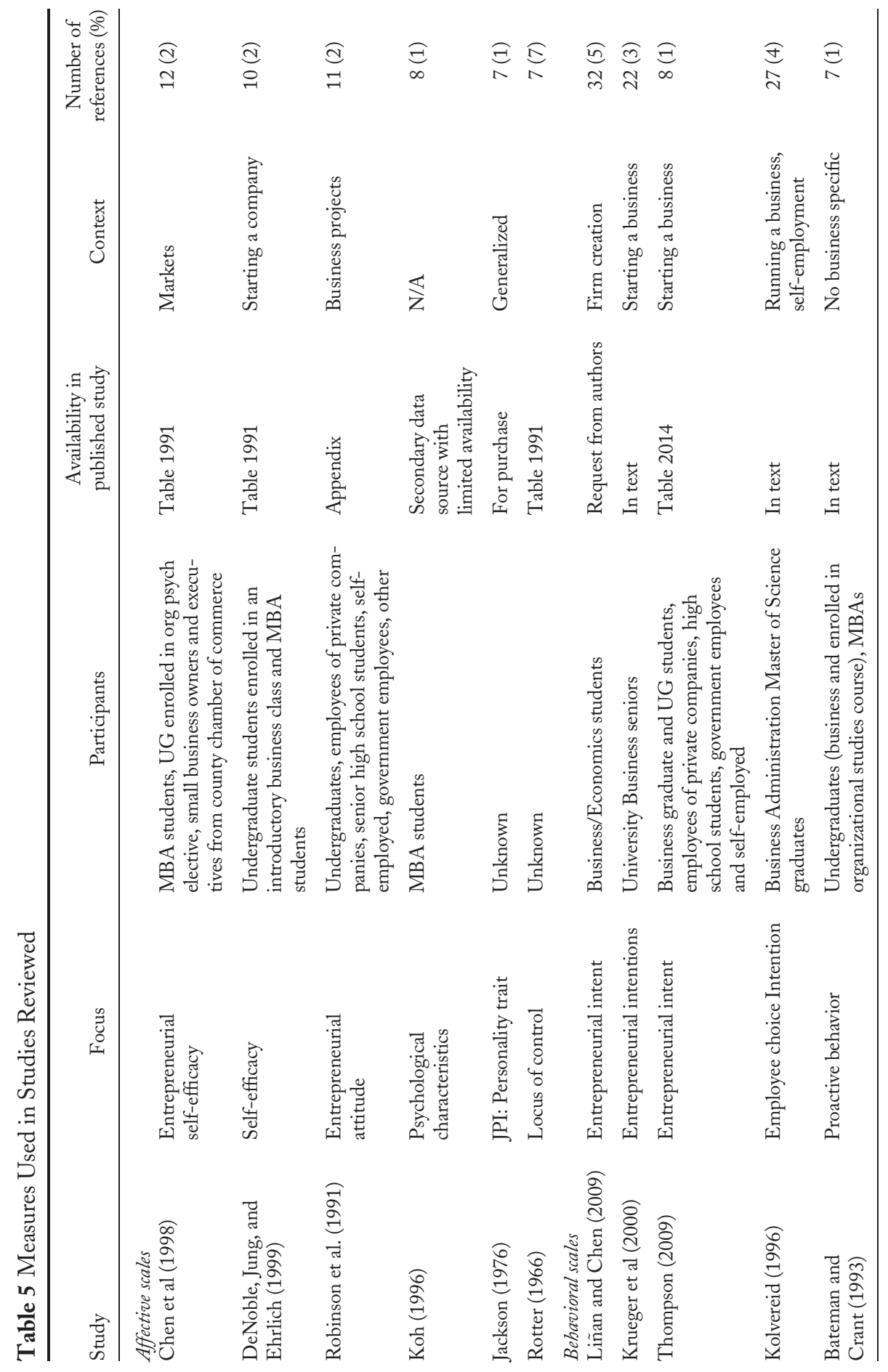


common affective measures evaluated self-efficacy, entrepreneurial attitude, and individual characteristics, while behavioral measures considered entrepreneurial intentions or proactive behaviors. Most of these measures are publically available, with the exception of the Jackson Personality Index (JPI). It is important to note that these measures, with the exception of the JPI and Rotter's locus of control, were primarily validated for business students.

A review of these most commonly used measures showed that the majority of the prompts for entrepreneurial self-efficacy, attitude, and intention are written in the context of starting a new business. Chen, Greene, and Crick (1998) offered a 5-factor scale (marketing, innovation, management, risk-taking, and financial control) for entrepreneurial self-efficacy based on entrepreneurial decision-making, "the decision to create and manage one's own business" (Chen et al. 1998, p. 301). Robinson, Stimpson, Huefner, and Hunt (1991) leveraged attitude theory to create the Entrepreneurial Attitude Orientation scale consisting of 4 constructs: achievement in business, innovation in business, perceived personal control of business outcomes, and perceived self-esteem in business. Forty-one of the 75 -items refer to work or a job environment. Entrepreneurial intent also specifically prompts responders for their intention to start a business (Liñán \& Chen, 2009) or become self-employed (Kolvereid, 1996).

\section{Validity and Reliability}

More than half $(n=232,65 \%)$ of the coded empirical studies mentioned validity or reliability. As previous researchers (Da Silva et al., 2015; Menold et al., 2015; Purzer et al., 2016) have reported, most entrepreneurship education studies include limited descriptions of instrument development and lack support for the validity and reliability of the instruments used. The majority of papers that cited validity and/or reliability simply reported Cronbach's alpha as a single measure of reliability. While it was not a focus of this paper to further discuss validity and reliability measures, both Menold et al. (2015) and Purzer et al. (2016) offer detailed frameworks for evaluating validity and reliability of methods.

\section{Engineering-Specific Literature}

This analysis was limited to engineering-specific studies published before September 3, 2015, meeting the inclusion and exclusion criteria seen in Table 1 . This analysis provides insight into the extent to which entrepreneurship education research in engineering settings compares to entrepreneurship education assessment across disciplines. One hundred eighty publications of the original 2,841 coded citations were published in 46 journals or proceedings with engineering in the title. Only 26 of the publications were empirical, with the first appearing in 2007 (Karanian, 2007). These 26 empirical studies represented $14 \%$ of all entrepreneurship engineering education publications as defined in this paper. Nineteen of the publications were published in the ASEE Annual Conference Proceedings, two in the International Journal of Engineering Education, and one in the Journal of Engineering Education.

While characterization studies are more common in the overall discipline of entrepreneurship education, an equal distribution between intervention and characterization studies is evident in the engineering entrepreneurship literature (Table 6). Engineering education researchers are also more likely to study undergraduate students, a focus that is not surprising given the fact that engineering institutions are actively pursuing educational reform and new assessment practices for undergraduate engineering programs (National Research Council, 2003; Singer, Nielsen, \& Schweingruber, 2012). Seventy-five percent of all entrepreneurship education assessment studies collected data on gender, whereas only $50 \%$ of the engineering 
Table 6 Descriptive Statistics of Engineering Entrepreneurship Education Empirical Studies

\begin{tabular}{lcc}
\hline Type of study & $\begin{array}{c}\text { Engineering } \\
\text { specific studies (\%) }\end{array}$ & $\begin{array}{c}\text { All empirical } \\
\text { studies (\%) }\end{array}$ \\
\hline Intervention & $13(50)$ & $119(33)$ \\
Characterization & $13(50)$ & $240(67)$ \\
Participants & & \\
Undergraduates & $21(81)$ & $270(75)$ \\
Graduate students & $1(4)$ & $84(23)$ \\
Undergraduate Alumni & $2(8)$ & $10(3)$ \\
Graduate Alumni & $0(0)$ & $10(3)$ \\
Faculty & $4(15)$ & $40(11)$ \\
Entrepreneurs & $3(12)$ & $24(7)$ \\
Disciplines & & \\
Business & $2(27)$ & $214(60)$ \\
Engineering & $22(85)$ & $72(20)$ \\
Other disciplines & $5(19)$ & $153(43)$ \\
Basic measures & & \\
Age & $12(46)$ & $206(57)$ \\
Gender & $13(50)$ & $255(71)$ \\
Ethnicity/race & $5(19)$ & $44(12)$ \\
Parents' education & $2(8)$ & $9(3)$ \\
Theories/experimental & & \\
protocol/measures & & \\
Theoretical framework & $1(4 \%)$ & $38(11)$ \\
Referenced theory & $6(23 \%)$ & $190(53)$ \\
Qualitative methods & $9(35 \%)$ & $68(19)$ \\
Quantitative methods & $19(73 \%)$ & $312(87)$ \\
Author used an existing scale & $10(38 \%)$ & $203(57)$ \\
Attempted validity/reliability testing & $10(38 \%)$ & $232(65)$ \\
\hline
\end{tabular}

studies documented gender. Few studies, both engineering and overall, documented race. Only one engineering study included the term theoretical framework and only six of the 26 papers referenced any theory prior to their methods sections. Overall, the engineering entrepreneurship education research community lags behind the broader entrepreneurship education assessment community in incorporating theory in empirical design ( $23 \%$ versus $53 \%$ ). The descriptive statistics suggest that the engineering education community also lags behind the broader community in the use of existing scales that have demonstrated validity (38\% versus $57 \%$ ) and reliability ( $38 \%$ versus $65 \%)$.

Similar to the papers reviewed overall, engineering-focused studies cited two of the most commonly referenced theories described above, TPB and SCT, in addition to leveraging Social Cognitive Career Theory and Psychosocial Development Theory. None of the engineeringfocused studies referenced Shapero's Model of Entrepreneurial Event. Twenty of the studies considered affective variables, ten, behavioral variables, and five, cognitive variables. Only 10 publications (37\%) used a previously developed scale, and only 11 of the 25 (41\%) discussed the validity and or trustworthiness of their scales, with the focus on Cronbach's alpha similar to the larger data set. 


\section{Study Limitations}

The purpose of this study was to synthesize a broad range of entrepreneurship education assessment literature in higher education research and to consider the nature of assessment in engineering entrepreneurship specifically. Its results are meant to offer engineering education research faculty a comprehensive understanding of the state of entrepreneurship education assessment and information on how to develop engineering education studies grounded in the appropriate theories, leveraging existing, reliable, and validated scales when appropriate. Nonetheless, it is important to recognize the limitations of this study. Most importantly, this paper was not meant to be an exhaustive systematic review of entrepreneurship theory; rather its purpose was to explore the extent to which theories are currently being used to frame entrepreneurship education assessment empirical research. Because of this approach, numerous conceptual entrepreneurship theories were not identified because they have not been explored empirically (e.g., Morris et al., 1994; Kuratko et al., 2015). The absence of such theories provides an opportunity for additional research.

We took a liberal approach to coding the theories used to frame the empirical studies. Given that the term theoretical framework is not utilized consistently across disciplines, publications coded as using theory to frame their studies were simply required to refer to a theory before the methods section of the paper. This approach to coding theory assumes that authors cognizant enough to describe theories in their introduction or background sections also incorporated these theories into their study design.

We also note challenges associated with reviewing 2,841 publications for exclusion and inclusion criteria and coding 359 publications. In particular, terminology differs across disciplines. The set of studies analyzed here resulted from a specific search string that may not have captured relevant papers using alternative terminologies. In addition, we chose not to code for study differences in operationalization because the majority of manuscripts did not explain how their data were collected. Finally, while many of the constructs measured in these studies were clearly defined, study authors did not always state clearly which variables their studies were measuring or were intended to measure. Establishing which variables were actually being measured was sometimes difficult, although we point readers to the high interrater reliability achieved for all codes.

\section{Discussion}

The recent rapid rise and adoption of entrepreneurship education in engineering offers an unprecedented opportunity for the research community to deepen its understanding of entrepreneurship education and to translate findings into practice. Research housed within the multidisciplinary field of entrepreneurship reflects a wide range of research traditions and norms communicated through various publication venues. This systematic review offers an opportunity to identify the relevant publication sources, reflect on the different traditions and norms for scholarship across fields, and identify the most effective research strategies for entrepreneurship education research moving forward. These are particularly important for engineering education researchers engaged in entrepreneurship studies given that engineering education as a field of scientific inquiry is still relatively young (Froyd \& Lohmann, 2014) and demonstrates limited grounding in theory (Table 6).

Since the early 2000s, entrepreneurship education research in both the business and engineering communities has experienced steady growth, spanning hundreds of different 
publications housed in multiple disciplines. As a result, identifying the relevant resources and theories informing studies in entrepreneurship education becomes a challenge. As demonstrated in this literature review, the number of first-order empirical studies that directly studied human subjects represented only $16 \%$ of all entrepreneurship education literature. Researchers new to the field must not only have the perseverance necessary to identify relevant research literature but must also be cognizant of the minimal overlap between database search engines, as demonstrated by the overlap of only 282 citations. Thus, scholars must be careful to search multiple databases to identify work that can inform future studies.

This review demonstrates that the majority of empirical findings are in the context of characterization studies (72\%), meaning that empirical studies on the impact of entrepreneurship education as an intervention at large are limited. Education intervention studies are particularly difficult to pursue at scale because of the challenges associated with controlling for the intervention. Adding a further challenge, entrepreneurship education is complex, varying in content, focus, and pedagogy. The recent agreement on the National Science Foundation Lean LaunchPad/I-Corps entrepreneurship curriculum (National Science Foundation, n.d.) may provide a platform for high quality intervention empirical studies moving forward.

While many studies analyzed in this review reference theories, very few clearly articulated the theoretical framework used to design a research approach and conduct the data analyses. Several theories, including the TPB (Ajzen, 1991), SCT (Bandura, 2001), and Shapero's Model of Entrepreneurial Event (Shapero \& Sokol, 1982), among others, seemed particularly relevant to entrepreneurship education. Engineering education researchers should choose one or more theories as the basis for their work. Doing so or applying other relevant theories that are established in higher education to frame future studies will enable researchers to leverage existing literature to interpret new findings and develop new theories relevant to engineering education contexts.

This review focused on empirical studies in higher education in particular, with a specific focus on studies of human subjects. Data were coded with respect to three variable categories, affect, behavior, and cognition, to identify major variable themes. Behavior, perhaps the most cited outcome of entrepreneurship education, was the least often studied of the three categories, a result that is expected given that behavior is difficult to measure. Affect, for which there are several good instruments deriving from a variety of fields, was the most commonly studied construct. The consequences of this research focus need to be considered. While changes in affect may ultimately produce behavioral changes, the link is not as clear as one might hope. For example, an increase in self-efficacy around entrepreneurship will not necessarily result in an individual engaging in entrepreneurial behaviors. Similarly, an improvement in knowledge about entrepreneurship, such as training through the Lean Launch curriculum, does not mean that entrepreneurship will follow. Positive affect and an increase in skills and knowledge may or may not translate into actual behavior. In addition, many of the theories cited by researchers were behavioral, illustrating a disconnect between the theory underpinning a study and the research design of the study itself.

This analysis found that the variables studied in entrepreneurship education are not necessarily mutually exclusive. Entrepreneurship education researchers are not consistent when defining variables and normalizing vocabulary. For example, where one researcher might collect participant attitude toward risk taking, another might merge risk taking into the broader entrepreneurial orientation construct. In addition, there does not appear to be a consistent practice for how demographic variables, such as gender, are measured. Given the lack of norms across the many communities engaged in entrepreneurship assessment in higher 
education, these inconsistencies make it challenging for cross-discipline synthesis and collaboration. Finally, a relative lack of cross-age and longitudinal studies in the literature was observed. Deep understanding of the impact of education requires consideration of impacts over time, especially because much of the impact of entrepreneurship education will not be experienced until long after students have graduated and entered the workforce.

\section{Implications for Engineering Entrepreneurship Education}

Entrepreneurship education assessment research emerged in the mid-1980s, experiencing significant growth since the turn of the 21st century. While entrepreneurship assessment research in business scholarship far outpaces other disciplines, engineering scholarship on entrepreneurship has also experienced significant growth since 2000. Existing studies share several characteristics, suggesting agreement within the entrepreneurship community about important areas of investigation as well as areas where new research is needed. Specifically:

1. Two-thirds of the collective entrepreneurship education assessment research is focused on characterizing entrepreneurship programs rather than measuring their outcomes, while the engineering-specific research exhibits an even distribution of characterization and intervention studies (albeit with few studies).

2. While just over $50 \%$ of the collective entrepreneurship education assessment papers reference theory, engineering-specific entrepreneurship education papers generally lack theoretical frameworks or connection to theory. In engineering, the entrepreneurship attribute most studied with respect to theory is entrepreneurial intent, defined as the intent to create a business.

3. While the collective entrepreneurship community explores a range of affective, behavioral, and cognitive measures, the latter are usually domain specific, such as business skills and financial literacy, rather than more generalizable professional skills. Engineering-specific entrepreneurship programs commonly focus on developing professional knowledge and skills, including creativity, opportunity identification, teamwork, and communication (Duval-Couetil et al., 2016), although there have been limited advances in capturing these broader student cognitive outcomes.

Given these common characteristics of entrepreneurship education assessment research, broadly, and within engineering specifically, several key areas for future research become evident. First, the community should work toward broader assessment of entrepreneurship educational programs to allow identification of those program characteristics that are most effective for meeting outcomes. With such outcome data, new programs can utilize effective components in program design. Second, the community should work toward a common practice of explicitly articulating theories underlying program development and research. Doing so will allow scholarship to link to the broader literature, thus providing a roadmap for the development of both new programs and assessment research. Finally, the unique nature of entrepreneurship in engineering programs provides an opportunity for new scholarship focused on the specific outcomes expected of engineers that are unique from the common outcomes measured in the broader entrepreneurship community.

Below, we provide several suggestions for researchers interested in engaging in entrepreneurship education research within engineering:

1. Leverage multiple databases The limited reference to theory and use of theoretical frameworks in engineering entrepreneurship assessment research may be a consequence of the 
highly interdisciplinary nature of the field (Kushkowski, 2012), the existence of multiple electronic databases (Bar-Ilan, 2008; Hood \& Wilson, 2003), and the range of research quality accepted for publication (Menold et al., 2015; Purzer et al., 2016). Engineering education research in itself is highly interdisciplinary, leveraging engineering, education, and cognitive science disciplines, among others (Singer et al., 2012). The subdiscipline of engineering entrepreneurship broadens this reach by incorporating business. Entrepreneurship education research also spans hundreds of different publications housed within multiple disciplines (Kushkowski, 2012). As a consequence, identifying the relevant resources and theories to inform the creation of high quality studies (Streveler \& Smith, 2006) in engineering-specific entrepreneurship education is a challenge, as demonstrated in other engineering education reviews (Pawley, Schimpf, \& Nelson, 2016). Engineering entrepreneurship education researchers must not only have the perseverance necessary to identify relevant, high-quality research literature, and be aware of differences in taxonomy (Jadine, Straf, Tanur, \& Tourangeau, 1984) but must also be cognizant of the minimal overlap between database search engines as a results of errors and inconsistency in the data and problems with coverage (Hood \& Wilson, 2003). This issue is demonstrated in our observation of an overlap of only 282 citations between two highly relevant databases.

2. Consider theory as applied to engineering entrepreneurship For the first 20 years of entrepreneurship education assessment research, researchers debated entrepreneurship as a discipline (Katz, 2008; Kuratko, 2006), the need for theory-driven research (Fayolle, 2013; Fiet, 2001), appropriate outcome measures (Maritz \& Brown, 2013; Mwasalwiba, 2010; Pittaway, Hannon, Gibb, \& Thompson, 2009), and rigorous development of measures (Liñán \& Chen, 2009; Mcgee, Peterson, Mueller, \& Sequeira, 2009). While engineering entrepreneurship assessment literature did not begin to appear until the turn of the 21 st century and lags behind the broader entrepreneurship community in number of publications, similar themes are mirrored in engineering. In particular, the engineering entrepreneurship education assessment community generally does not link theory to research. Only $23 \%$ of the engineeringrelated scholarship referenced a theory in contrast to $53 \%$ of the studies overall. This gap closes only when studies making a clear articulation of a theoretical framework used to design a research study are considered (11\% and $4 \%$, general community and engineering-specific, respectively). As these differences suggest, the entrepreneurship education community, and not just engineers, need to do a better job of linking theory to research activity.

As engineering education researchers consider framing their entrepreneurship research within the context of existing theories, researchers should view how each theory defines the variables being examined and how hypotheses emerge from theory. Existing theories may not provide the necessary foundation for entrepreneurship research in all higher education spaces. In these cases, researchers are encouraged to develop new theories from data through grounded methodologies. For example, the business entrepreneurship research community extensively uses Ajzen's (1991) TPB as a model for studying entrepreneurial intent (Fayolle, Gailly, \& Lassas-Clerc, 2006; Krueger, Reilly, \& Carsrud, 2000) and assessing the impact of educational programs on intention antecedents (e.g., subjective norm, perceived behavioral control and attitude). While numerous studies have shown that TPB can be used as a predictor of entrepreneurial intent in business students, measures emerging from TPB have all been validated in the context of starting a business, with students generally being evaluated based on their perceptions of business creation. However, business creation may not be the appropriate outcome metric for engineering entrepreneurship education. In fact, a study by Bae, Qian, Miao, and Fiet (2014) found that the relationship between entrepreneurship 
intent and entrepreneurship education was not significant when they controlled for preeducation entrepreneurial intent (Bae et al., 2014). Engineering faculty need to consider if business creation is the end goal of their educational efforts and to decide how to apply TPB in the engineering context.

Current engineering entrepreneurship literature indicates that the scope of engineering entrepreneurship programs focuses on global entrepreneurship rather than on business creation (Duval-Couetil et al., 2016; Gilmartin et al., 2016; Sheppard et al., 2015), a significant departure from entrepreneurship programs housed in business colleges. Program directors explicitly state that engineering entrepreneurship programs seek to develop transferrable skill sets applicable to diverse settings. Currently available measures focusing on business creation may not be directly transferrable to engineering education research and, thus, may leave important outcomes unmeasured. Given the broad scope of engineering entrepreneurship, engineering education researchers should consider engineering-specific measures, such as creativity, product development, opportunity identification, teamwork, and communication

3. Evaluate validity and reliability Development of measures for assessment is both complex and time-consuming (e.g., DeVellis, 2012). Thus, it benefits the engineering entrepreneurship education community to leverage existing measures when appropriate, although caution must be taken to apply only those that are valid in an engineering context, meaning those developed for other contexts should be evaluated for their applicability. In addition, researchers must clearly establish what they want to measure and how to avoid validity problems and bias effects (MacKenzie, 2003).

Study results indicate that the most commonly used measures in entrepreneurship education assessment research are grounded in business and have been largely validated with business students (Table 5). Engineering education faculty interested in using existing measures should first validate these as appropriate instruments for engineering students as not all instruments are transferable to all populations. This transferability challenge was demonstrated by Fernandes, Coutinho, Wilson, and Hoffmann (2015), who attempted to modify the Robinson et al. Entrepreneurial Attitudes Orientation scale (Robinson et al., 1991) for engineering students and were unable to validate it for that population. This finding further demonstrates in the importance of initial validation so that researchers do not misinterpret data.

4. Establish shared definitions Challenges associated with inconsistent terminology have been a point of debate in entrepreneurship education literature since at least 2001 (Davidsson, Low, \& Wright, 2001; Low, 2001; Thrane, Blenker, Korsgaard, \& Neergaard, 2016) and is believed to limit the ability of the field to advance (Thrane et al., 2016). Several business entrepreneurship education scholars have argued for a shared conceptual framework (Blenker, Korsgaard, Neergaard, \& Thrane, 2011; Mwasalwiba, 2010; Pittaway \& Cope, 2007), including shared definitions and methods (Davidsson et al., 2001; Low, 2001). This discourse is also evident in engineering entrepreneurship education research. For example, while 19 of the engineering-specific papers identified in this review refer to a "mindset" and call for the need to develop the future global engineer, what the entrepreneurial mindset means for the engineer and how it can be measured are ongoing conversations. The definition of mindset varied across the 19 papers from leadership (Karanian, 2007) to business creation (BesterfieldSacre et al., 2012; Duval-Couetil, Reed-Rhoads, \& Haghighi, 2010) to professional skills (Sánchez, Álvarez, \& Iborra, 2014). This lack of consensus points to the important need for engineering entrepreneurship education researchers to either work toward a shared definition of the entrepreneurial mindset or more importantly, clearly define their use of the term 
in their research such that the appropriate instruments grounded in the appropriate theories are used. Is a mindset a skill, a competency, an affect, a behavior, or a combination of these? What constructs constitute mindset? How can the community use mindset, or any term for that matter, so that we have a shared understanding of published research? Most importantly, this conversation should link to the broader entrepreneurship community to ensure work emerging from engineering is transferable to other disciplinary settings.

Proposing a standardization of terms or taxonomy is not meant to limit the scope of engineering entrepreneurship education research but to facilitate more robust research and a fuller understanding of engineering entrepreneurship research. This proposed taxonomy could be used across studies as the engineering entrepreneurship community looks to create more evidence-based practices that impact entrepreneurship education and students. With common definitions and a common understanding, researchers can determine the appropriate theories that can be applied to engineering entrepreneurship education research and assessment and examine the underlying assumptions made in assessment research. This standardization will help engineering education researchers determine what engineering appropriate constructs should be measured and identify where previously developed measures can be leveraged or where new measures must be developed and tested for validity and reliability for use with engineering students.

\section{Relevance to Future Research and Practice}

Regardless of the state of theory and assessment, in practice engineering education has signaled that entrepreneurship is becoming a priority. As the nation's economic future becomes increasingly dependent on innovation, engineering colleges and universities are creating specific programs to encourage engineers to be entrepreneurially minded (Gilmartin et al., 2016; Shartrand et al., 2010). Unlike traditional business programs that focus on encouraging students that self-select into entrepreneurship, many engineering programs seek to expose all engineering students to entrepreneurial thinking regardless of their intent to start a company (Byers et al., 2013; Gilmartin et al., 2016). While this objective is ambitious, this literature review demonstrates that there are limited assessment tools to support programs in measuring student outcomes and validating their efforts. Given that these initiatives are complex, laborintensive curricular and co-curricular programs, the engineering education community has a unique opportunity to develop critical tools and instruments that can be used to explore the impact of engineering entrepreneurship education: What type of student engages in entrepreneurship education? What motivates students to engage? Is there a change in attitude, knowledge, or behavior in students that do not self-select into entrepreneurship programs? Are these questions gendered? How does the entrepreneurial mindset differ from the design mindset? Currently, these two streams of engineering education are separate; could they be integrated? Most importantly, answers to such questions can be used to formatively shape program development in real time so that entrepreneurship education is accessible to and impactful for all students.

\section{Conclusions}

This systematic review indicates a steady growth in entrepreneurship education assessment research in both business-specific and engineering-specific scholarship since the early 2000s. While both of these areas of research demonstrate similar trends in growth, the literature on assessment of engineering-specific entrepreneurship education significantly lags its business 
counterpart. Entrepreneurship research literature spans hundreds of different publications housed within multiple disciplines with little exchange of ideas across the disciplines of business, engineering, and education. As a result, while engineering should look to leverage existing literature to advance engineering entrepreneurship research, identifying relevant resources and theories to inform studies in engineering entrepreneurship education becomes a challenge. Our analysis also shows that nonempirical descriptions of programs outweigh empirical research and there is limited use of theoretical frameworks, thus limiting our ability to generalize findings and translate findings into practice at scale. At the same time, while there have been some efforts to leverage pre-existing literature, outcomes are often not aligned with engineering outcomes, or assessment instruments have shown to be invalid for engineering students. Both of these indicate that engineering should leverage existing literature to further develop engineering-specific theories and frameworks.

If engineering is successful in developing a shared vocabulary, a foundation of theory that builds on what has already been explored, and validated, reliable scales, more pressing engineering-specific entrepreneurship questions and theories can be explored and developed. Drawing on existing entrepreneurship education research will help engineering education researchers ground their work in established theories and identify variables and instruments to initially explore. These findings will determine the validity of such theories and instruments for studying engineering students and lay the foundation for establishing new engineering entrepreneurship theories, should they be necessary.

The widespread implementation of entrepreneurship and innovation programs in engineering curricula also offers unique opportunities. Entrepreneurship education research has the opportunity to shift from traditional characteristic studies to impact studies. Rather than just focusing on attributes of entrepreneurs and students who self-select entrepreneurial opportunities, research can explore how to create entrepreneurial environments that support the majority. As a result, these evidence-based findings can be used to iterate educational practice in real time. Engineering entrepreneurship programs have evolved to become complex, labor-intensive educational environments, integrating pedagogy, mentorship, and cocurricular programming. By rigorously unpacking engineering entrepreneurship education, there is the potential to create more effective, inclusive, and scalable engineering education programs that will lead to the innovative and entrepreneurial engineers needed in the 21st century.

\section{Acknowledgments}

The authors thank the National Science Foundation for the support of this work (NSF IUSE-1504257 and REE-1531533).

\section{References}

Ajzen, I. (1991). The theory of planned behavior. Organizational Behavior and Human Decision Processes, 50(2), 179. http://doi.org/10.1016/0749-5978(91)90020-T

Bae, T. J., Qian, S., Miao, C., \& Fiet, J. O. (2014). The relationship between entrepreneurship education and entrepreneurial intentions: A meta-analytic review. Entrepreneurship Theory and Practice, 38(2), 217-254. http://doi.org/10.1111/etap.12095

Bandura, A. (1986). Social foundations of thought and action: A social cognitive theory. Englewood Cliffs, NJ: Prentice-Hall. http://doi.org/10.2307/2071177 
Bandura, A. (2001). Social cognitive theory: An agentic perspective. Annual Review of Psychology, 52(1), 1-26. http://doi.org/10.1146/annurev.psych.52.1.1

Bar-Ilan, J. (2008). Informetrics at the beginning of the 21st century-A review. Journal of Informetrics, 2(1), 1-52. http://doi.org/10.1016/j.joi.2007.11.001

Bateman, T., \& Crant, J. M. (1993). The proactive component of organizational behavior: A measure and correlates. Journal of Organizational Behavior, 14(2), 103-118.

Belitski, M., \& Heron, K. (2017). Expanding entrepreneurship education ecosystems. Journal of Management Development, 36(2), 163-177. http://doi.org/10.1108/JMD-06-2016-0121

Besterfield-Sacre, M., Robinson, A. M., Zaltin, N. Z., Shuman, L. J., Shartrand, A. M., \& Weilerstein, P. (2012). Essential factors related to entrepreneurial knowledge in the engineering curriculum. Proceedings of the American Society for Engineering Education, San Antonio, TX.

Blenker, P., Korsgaard, S., Neergaard, H., \& Thrane, C. (2011). The questions we care about: Paradigms and progression in entrepreneurship education. Industry and Higher Education, 25(6), 417-427. http://doi.org/10.5367/ihe.2011.0065

Blessing, J., Mekemson, K., \& Pistrui, D. (2008). Building an entrepreneurial engineering ecosystem for future generations: The Kern Entrepreneurship Education Network. Proceedings of the American Society for Engineering Education, Pittsburgh, PA.

Borrego, M., Foster, M. J., \& Froyd, J. E. (2014). Systematic literature reviews in engineering education and other developing interdisciplinary fields. Journal of Engineering Education, 103(1), 45-76. http://doi.org/10.1002/jee.20038

Byers, T., Seelig, T., Sheppard, S., \& Weilerstein, P. (2013). Entrepreneurship: Its Role in Engineering Education. The Bridge, 43(2), 35-40.

Chen, C. C., Greene, P. G., \& Crick, A. (1998). Does entrepreneurial self-efficacy distinguish entrepreneurs from managers? Journal of Business Venturing, 13(4), 295-316. http:// doi.org/10.1016/S0883-9026(97)00029-3

Colby, A., Ehrlich, T., \& Sullivan, W. (2011). Rethinking undergraduate business education: Liberal learning for the profession. Stanford, CA: The Carnegie Foundation for the Advancement of Teaching.

Da Silva, G. B., Costa, H. G., \& de Barros, M. D. (2015). Entrepreneurship in engineering education: A literature review. International Journal of Engineering Education, 31(6), 17011710.

Daniel, T., \& Kent, C. (2005). An assessment of youth entrepreneurship programs in the United States. Journal of Private Enterprise, 20(2), 126-147.

Davidsson, P., Low, M. B., \& Wright, M. (2001). Editor's introduction: Low and MacMillan ten years on: Achievements and future directions for entrepreneurship research. Entrepreneurship Theory \& Practice, Summer, 5-15. http://doi.org/10.1177/1056492601103005

DeNoble, A. F., Jung, D., \& Ehrlich, S. B. (1999). Entrepreneurial self-efficacy: The development of a measure and its relationship to entrepreneurial action. In K. G. Reynolds et al. (Eds.), Frontiers of Entrepreneurship Research. Wellesley, MA: P\&R Publication Inc.

DeVellis, R. F. (2012). In L. Bickman \& D. J. Rog (Eds.), Scale development: Theory and applications (3rd ed.). Thousand Oaks, CA: Sage Publications.

Duval-Couetil, N. (2013). Assessing the impact of entrepreneurship education programs: Challenges and approaches. Journal of Small Business Management, 51(3), 394-409. http:// doi.org/10.1111/jsbm.12024

Duval-Couetil, N., Reed-Rhoads, T., \& Haghighi, S. (2010). Development of an assessment instrument to examine outcomes of entrepreneurship education on engineering students. 
Proceedings of the 2010 IEEE Frontiers in Education Conference (FIE), Washington, DC. http://doi.org/10.1109/FIE.2010.5673411

Duval-Couetil, N., Shartrand, A., \& Reed-Rhoads, T. (2016). The role of entrepreneurship program models and experiential activities on engineering student outcomes. Advances in Engineering Education, 5(1), 1-27.

Engineering, N. A. O. (2005). The Engineer of 2020: Visions of Engineering in the New Century Engineering. Washington, DC: The National Academies Press. http://doi.org/http:// www.nap.edu/catalog/10999.html

Fayolle, A. (2013). Personal views on the future of entrepreneurship education. Entrepreneurship E Regional Development, 25(7-8), 692-701. http://doi.org/10.1080/08985626.2013. 821318

Fayolle, A., Gailly, B., \& Lassas-Clerc, N. (2006). Assessing the impact of entrepreneurship education programmes: A new methodology. Journal of European Industrial Training, 30(9), 701-720. http://doi.org/10.1108/03090590610715022

Fernandes, T. M., Coutinho, G. S., Wilson, M. D., \& Hoffmann, S. R. (2015). Development of entrepreneurial attitudes assessment instrument for freshman students. Proceedings of the American Society for Engineering Education, Seattle, WA. http://doi.org/10.18260/p.23874

Fiet, J. (2001). The theoretical side of teaching entrepreneurship. Journal of Business Venturing, 9026(99), 1-24. http://doi.org/10.1016/S0883-9026(99)00041-5

Fishbein, M., \& Ajzen, I. (1975). Belief, attitude, intention, and behavior, an introduction to theory and research. Reading, MA: Addison-Wesley Publishing Co. http://doi.org/10. 1016/B978-0-12-375000-6.00041-0

Froyd, J. E., \& Lohmann, J. R. (2014). Chronological and ontological development of engineering education. In A. Johri \& B. M. Olds (Eds.), Cambridge handbook of engineering education research (1st ed., pp. 3-15). New York, NY: Cambridge University Press. http:// doi.org/10.1111/cobi.12328

Fry, C., Jordan, W., Leman, G., Garner, B., \& Thomas, B. (2010). Bringing innovation and the entrepreneurial mindset (back) into engineering: The KEEN Innovators Program. Proceedings of the American Society for Engineering Education, Louisville, KY.

Gilmartin, S. K., Chen, H. L., \& Estrada, C. (2016). Investigating entrepreneurship program models in undergraduate engineering education. International Journal of Engineering Education, 32(5), 2048-2065.

Gompers, P. A. (1994). The rise and fall of venture capital. Business and Economic History, 23(2), 1-26. http://doi.org/10.2307/23702914

Hood, W. W., \& Wilson, C. S. (2003). Informetric studies using databases: Opportunities and challenges. Scientometrics, 58(3), 587-608. http://doi.org/10.1023/B:SCIE.000000 6882.47115.c6

Jackson, D. N. (1976). Jackson personality inventory manual. Port Huron, MI: Research Psychologists Press.

Jadine, T. B., Straf, M. L., Tanur, J. M., \& Tourangeau, R. (1984). Cognitive aspects of survey methodology: Building a bridge between disciplines. Washington, DC: The National Academies Press.

Karanian, B. (2007). Entrepreneurial leadership and transformational change. Proceedings of the American Society for Engineering Education, Honolulu, HI.

Katz, J. A. (2003). The chronology and intellectual trajectory of American entrepreneurship education 1876-1999. Journal of Business Venturing, 18(2), 283-300. http://doi.org/ 10.1016/S0883-9026(02)00098-8 
Katz, J. A. (2008). Fully mature but not fully legitimate: A different perspective on the state of entrepreneurship education. Journal of Small Business Management, 46(4), 550-566. http://doi.org/10.1111/j.1540-627X.2008.00256.x

Kauffman Foundation. (2010). Youth entrepreneurship poll fact sheet 2010. Kansas City, KS: Kauffman Foundation.

Koh, H. C. (1996). Testing hypotheses of entrepreneurial characteristics: A study of Hong Kong MBA students. Journal of Managerial Psychology, 11(3), 12-25. http://doi.org/10. 1108/02683949610113566

Kolvereid, L. (1996). Prediction of employment status choice intentions. Entrepreneurship Theory and Practice, 21(1), 47-57.

Krueger, N. F., Reilly, M. D., \& Carsrud, A. L. (2000). Competing models of entrepreneurial intentions. Journal of Business Venturing, 15(5-6), 411-432. http://doi.org/10.1016/ S0883-9026(98)00033-0

Kuratko, D. F. (2005). The emergence of entrepreneurship education: Development, trends and challenges. Entrepreneurship Theory and Practice, 29(5), 577-597. http://doi.org/ 10.1111/j.1540-6520.2005.00099.x

Kuratko, D. F. (2006). A tribute to 50 years of excellence in entrepreneurship and small business. Journal of Small Business Management, 44(2), 151-154. http://doi.org/10.1111/ j.1540-627X.2006.00159.x

Kuratko, D. F., Morris, M. H., \& Schindehutte, M. (2015). Understanding the dynamics of entrepreneurship through framework approaches. Small Business Economics, 45(1), 1-13. http://doi.org/10.1007/s11187-015-9627-3

Kushkowski, J. D. (2012). Charting the growth of entrepreneurship: A citation analysis of FER content, 1981-2008. Journal of Business E Finance Librarianship, 17(3), 201-219. http://doi.org/10.1080/08963568.2012.685035

Liñán, F., \& Chen, Y. W. (2009). Development and cross-cultural application of a specific instrument to measure entrepreneurial intentions. Entrepreneurship Theory and Practice, 33(3), 593-617. http://doi.org/10.1111/j.1540-6520.2009.00318.x

Loi, M., Castriotta, M., \& Di Guardo, M. C. (2016). The theoretical foundations of entrepreneurship education: How co-citations are shaping the field. International Small Business Journal, 34(7), 948-971. http://doi.org/10.1177/0266242615602322

Low, M. B. (2001). The adolescence of entrepreneurship research: Specification of purpose. Entrepreneurship Theory and Practice, 25, 17-26.

MacKenzie, S. B. (2003). The dangers of poor construct conceptualization. Journal of the Academy of Marketing Science, 31(3), 323-326. http://doi.org/10.1177/0092070303254130

Maritz, A., \& Brown, C. R. (2013). Illuminating the black box of entrepreneurship education programs. Education and Training, 55(3), 234-252. http://doi.org/10.1108/004009113 11309305

Massy, W. F., Sullivan, T. A., \& Mackie, C. (2013). Improving measurement of productivity in higher education. Change: The Magazine of Higher Learning, 45(1), 15-23. http://doi. org/10.1080/00091383.2013.749140

Mcgee, J. E., Peterson, M., Mueller, S. L., \& Sequeira, J. M. (2009). Entrepreneurial selfefficacy: Refining the measure. Entrepreneurship Theory and Practice, 33(4), 965-988. http://doi.org/10.1111/j.1540-6520.2009.00304.x

McGowan, J., \& Sampson, M. (2005). Systematic reviews need systematic searchers. Journal of the Medical Library Association, 93(1), 74-80. 
Menold, J., Jablokow, K., Zappe, S., Reeves, P., \& Kisenwether, L. (2015). Best practices in survey development for evaluation of student gains from entrepreneurship programs and classes. In VentureWell Open (pp. 1-10). Washington, DC.

Morris, M. H., Lewis, P. S., \& Sexton, D. L. (1994). Reconceptualizing entrepreneurship: An input-output perspective. SAM Advanced Management Journal, 59(1), 21-31.

Mwasalwiba, E. S. (2010). Entrepreneurship education: A review of its objectives, teaching methods, and impact indicators. Education E Training, 52(1), 20-47. http://doi.org/ http://dx.doi.org/10.1108/00400911011017663

National Academy of Sciences, National Academy of Engineering. (2007). Rising above the gathering storm: Energizing and employing America for a brighter economic future. Washington, DC: National Academy of Sciences, National Academy of Engineering. http:// doi.org/10.1080/09500690701644266

National Academy of Sciences, National Academy of Engineering. (2010). Rising above the gathering storm, revisitng: Rapidly approaching category 5. Washington, DC: National Academy of Sciences, National Academy of Engineering. http://doi.org/10.1890/00129623(2006)87[46:TGS]2.0.CO;2

National Research Council. (2003). Evaluating and improving undergraduate teaching in science, technology, engineering, and mathematics. Washington, DC: National Research Council. http://doi.org/10.1002/bmb.2003.494031059998

National Science Foundation. (n.d.). National Science Foundation Lean LaunchPad I-Corps Curriculum. Retrieved May 10, 2016, from www.nsf.gov/news/special_reports/i-corps/ curriculum.jsp

Neck, H. M., Greene, P. G., Branson, R., \& Ash, M. K. (2011). Entrepreneurship education: Known worlds. Journal of Small Business Management, 49(1), 55-70. http://doi.org/ 10.1111/j.1540-627X.2010.00314.x

Pawley, A. L., Schimpf, C., \& Nelson, L. (2016). Gender in engineering education research: A content analysis of research in JEE, 1998-2012. Journal of Engineering Education, 105(3), 508-528. http://doi.org/10.1002/jee.20128

Peterfreund, A. R., Costache, E., Chen, H. L., Gilmartin, S. K., \& Sheppard, S. (2016). Infusing innovation and entrepreneurship into engineering education: Looking for change as seen by ASEE Members, 2012 to 2015. Proceedings of the American Society for Engineering Education, New Orleans, LA. http://doi.org/10.18260/p.25691

Pittaway, L., \& Cope, J. (2007). Entrepreneurship education: A systematic review of the evidence. International Small Business Journal, 25(5), 479-510. http://doi.org/10.1177/ 0266242607080656

Pittaway, L., Hannon, P., Gibb, A., \& Thompson, J. (2009). Assessment practice in enterprise education. International Journal of Entrepreneurial Behaviour E Research, 15(1), $71-$ 93. http://doi.org/10.1108/13552550910934468

Purzer, S., Fila, N. D., \& Nataraja, K. (2016). Evaluation of current assessment methods in engineering entrepreneurship education. Advances in Engineering Education, 1-13.

Rae, D. (2010). Universities and enterprise education: Responding to the challenges of the new era, 17(4), 591-606. http://doi.org/10.1108/14626001011088741

Regele, M. D., \& Neck, H. M. (2012). The entrepreneurship education sub-ecosystem in the United States: Opportunities to increase entrepreneurial activity. Proceedings of the United States Association for Small Business and Entrepreneurship (pp. 652-669).

Reynolds, P. D., Camp, S. M., Bygrave, W. D., Autio, E., \& Hay, M. (2000). Global entrepreneurship monitor: 2000 Executive report. Kansas City, MO. 
Robinson, P. B., Stimpson, D. V., Huefner, J. C., \& Hunt, H. K. (1991). An attitude approach to the predication of entrepreneurship. Entrepreneurship Theory and Practice, Summer, 13-31.

Rotter, J. B. (1966). Generalized expectancies for internal versus external control of reinforcement. Psychological Monographs: General and Applied, 80(1), 1-28. http://doi.org/10.1037/ h0092976

Sánchez, P., Álvarez, B., \& Iborra, A. (2014). Improving transferable skills in engineering education through a pre-incubation semester. International Journal of Engineering Education, 30(4), 862-875.

Shane, S., \& Venkataraman, S. (2000). The promise of entrepreneurship as a field of research. Academy of Management Review, 25(1), 217-226. http://doi.org/10.5465/AMR. 2000.2791611

Shapero, A., \& Sokol, L. (1982). The social dimensions of entrepreneurship. In D. Sexton \& K. Vesper (Eds.), Encyclopedia of entrepreneurship (pp. 72-90). Englewood Cliffs, NJ: Prentice-Hall. http://doi.org/10.1080/09614520701469617

Shartrand, A., Weilerstein, P., Besterfield-Sacre, M., \& Golding, K. (2010). Technology entrepreneurship programs in U.S. engineering schools: Course and program characteristics at the undergraduate level. Proceedings of the American Society for Engineering Education, Louisville, KY.

Sheppard, S., Gilmartin, S., Chen, H. L., Besterfield-Sacre, M. E., Duval-Couetil, N., Shartrand, A., ... Breed, A. K. (2015). Exploring what we don't know about entrepreneurship education for engineers. Proceedings of the American Society for Engineering Education, Seattle, WA. http://doi.org/10.18260/p.24083

Singer, S. R., Nielsen, N. R., \& Schweingruber, H. A. (Eds.). (2012). Discipline-based education research: Understanding and improving learning in undergraduate science and engineering. Washington, DC: National Academy Press. http://doi.org/10.17226/13362

Sorgman, M., \& Parkison, K. (2008). The future is now: Preparing K-12 teachers and students for an entrepreneurial society. Journal of Entrepreneurship Education, 11, 75-86.

Standish-Kuon, T., \& Rice, M. P. (2002). Introducing engineering and science students to entrepreneurship: Models and influential factors at six American universities. Journal of Engineering Education, 91(1), 33-39. http://doi.org/10.1002/j.2168-9830.2002.tb00670.x

Streveler, R. A., \& Smith, K. A. (2006). Conducting rigorous research in engineering education. Journal of Engineering Education, April, 103-105. http://doi.org/10.1002/j.21689830.2006.tb00882.x

Thompson, E. R. (2009). Individual entrepreneurial intent: Construct clarification and development of an internationally reliable metric. Entrepreneurship Theory and Practice, 33(3), 669-694. http://doi.org/10.1111/j.1540-6520.2009.00321.x

Thrane, C., Blenker, P., Korsgaard, S., \& Neergaard, H. (2016). The promise of entrepreneurship education: Reconceptualizing the individual-opportunity nexus as a conceptual framework for entrepreneurship education. International Small Business Journal, 34(7), 905-924. http://doi.org/10.1177/0266242616638422

VentureWell. (2016). Directory of I-Corps ${ }^{\text {TM }}$ Nodes and Sites. Retrieved January 20, 2016, from https://venturewell.org/i-corps/nodes-and-sites/

Vesper, H., \& Gartner, B. (1997). Measuring progress in entrepreneurship education. Journal of Business Venturing, 12, 403-421. http://doi.org/10.1016/S0883-9026(97)00009-8

Wasley, P. (2008). Entrepreneurship 101: Not just for business school any more. Chronicle of Higher Education, 54(41), 1. 


\section{Authors}

Aileen Y. Huang-Saad is an assistant professor of biomedical engineering, engineering education and entrepreneurship at University of Michigan, 2228 LBME, 1101 Beal Avenue, Ann Arbor, MI, 48109; aileenhs@umich.edu.

Christina S. Morton is a doctoral candidate in the Center for the Study of Higher and Postsecondary Education at the University of Michigan, 610 E. University Avenue, CSHPE Suite 2117, Ann Arbor, MI 48109-1259; cspr@umich.edu.

Julie C. Libarkin is a professor of earth and environmental science at Michigan State University, 288 Farm Lane, 206 Natural Science East Lansing, MI 48824; libarkin@msu.edu. 